\title{
PENGARUH ETOS KERJA DAN KEPUASAN KERJA TERHADAP DISIPLIN KERJA PEGAWAI PADA KANTOR PELAYANAN PERBENDAHARAAN NEGARA (KPPN) PEMATANGSIANTAR
}

\author{
Oleh: \\ Pradita \\ S1 Manajemen \\ Darwin Lie, Efendi, Ady Inrawan
}

Abstraksi

Adapun rumusan masalah penelitian ini adalah bagaimana pengaruh etos kerja dan kepuasan kerja terhadap disiplin kerja pegawai pada Kantor Pelayanan Perbendaharaan Negara (KPPN) Pematangsiantar. Metode penelitian yang digunakan dalam penulisan ini adalah penelitian kepustakaan dan penelitian lapangan. Populasi dan sampel adalah pegawai negeri sipil Kantor Pelayanan Perbendaharaan Negara (KPPN) Pematangsiantar berjumlah 28 orang. Mengingat jumlah responden kurang dari 100 orang untuk menjawab kuesioner yang penulis sebarkan dan ketersediaan waktu penulis serta untuk keakuratan hasil penelitian. Dalam penelitian ini menggunakan data kualitatif dan data kuantitatif dan teknik pengumpulan data dengan cara kuesioner, wawancara dan dokumentasi. Kemudian teknik analisa data menggunakan metode deskriptif kualitatif dan metode deskriptif kuantitatif.

Hasil analisa dari regresi linier berganda yaitu $\hat{Y}=35,010+0,491 X_{1}+0,763 X_{2}$ artinya terdapat pengaruh positif antara etos kerja dan kepuasan kerja terhadap disiplin kerja pegawai. Kekuatan hubungan ketiga variabel adalah sangat kuat, yaitu $r=0,781$. Dari koefisien determinasi dapat dijelaskan tinggi rendahnya kinerja karyawan $61 \%$, dan sisanya $39 \%$ dijelaskan oleh faktor lainnya yang yang tidak dibahas dalam penelitian ini. Dari hasil pengolahan dan perhitungan kuesioner, penulis mendapatkan kesimpulan bahwa kualitas etos kerja dan kepuasan kerja yang diterapkan Kantor Pelayanan Perbendaharaan Negara (KPPN) Pematangsiantar berpengaruh positif dan signifikan terhadap disiplin kerja pegawai. Hal ini dibuktikan melalui uji hipotesis secara simultan, dimana hasil uji $f_{\text {hitung }}(19,537)>\mathrm{f}_{\text {tabel }}(3,39)$ dengan taraf signifikansi $0,000<$ alpha 0,05 .

Kata Kunci: Etos Kerja, Kepuasan Kerja, Disiplin Kerja Pegawai

\section{Abstraction}

As for this research problem formula is how work ethics and job satisfaction on working discipline at Kantor Pelayanan Perbebndaharaan Negara (KPPN) Pematangsiantar. Research Method used in this writing is library research and field research. Its population and sample is employees Pelayanan Perbebndaharaan Negara (KPPN) Pematangsiantar amount to 28 people. Considering responder amount less than 100 people to reply the questionnaires which writer propagate and availibility of writer time and also for the accuracy of result of research. In this study using qualitative data and quantitative data, and technique of data collecting by questionnaires, interview and documentation. Then technique analyse the data use the descriptive method qualitative and quantitative descriptive method.

Result of analysis from linear regresi modestly that is $\hat{Y}=35,010+0,491 X_{1}+0,763 X_{2}$ meaning there are positive influence work ethics and job satisfaction on working discipline at Kantor Pelayanan Perbebndaharaan Negara (KPPN) Pematangsiantar. The strength of relationship between the variables is very strength, that is $r=$ 0,781. From coefficient determinasi can explainable high and low of customer's purchase decision $61 \%$, and the rest $39 \%$ explained by other factor which is not discussed in this research. From result of processing and calculation questionnaires, writer get the conclusion that work ethics and job satisfaction applied by work ethics and job satisfaction on working discipline at Kantor Pelayanan Perbebndaharaan Negara (KPPN) Pematangsiantar.an effect on to working discipline. This matter is proved by hypothesis test either simultaneously where result test the $f_{\text {hitung }}(19,537)>f_{\text {tabel }}(3,39)$ and which significant $0,000<$ alpha 0,05 .

Keywords: Work Ethics, Job Satisfaction, Working Discipline

\section{A. Pendahuluan}

\section{Latar Belakang Masalah}

Kantor Pelayanan Perbendaharaan Negara merupakan perpanjangan tangan dari Menteri Keuangan sebagai Bendahara Umum Negara di daerah yang berkaitan erat dengan proses pencairan dan pertanggung jawaban dana yang bersumber dari Anggaran Pendapatan dan Belanja Negara (APBN). Kantor Pelayanan Perbendaharaan Negara (KPPN)
Pematangsiantar senantiasa mengadaptasi program dan teknologi baru untuk mendukung disiplin kerja pegawai.

Disiplin kerja merupakan sikap menghormati, menghargai, patuh dan taat terhadap peraturanperaturan yang berlaku baik yang tertulis maupun tidak tertulis. Disiplin kerja pada Kantor Pelayanan Perbendaharaan Negara (KPPN) Pematangsiantar ditinjau dalam PP Nomor 53 Tahun 2010 tentang 
disiplin PNS yang berupa kewajiban yang harus dijalankan dan larangan-larangan yang harus dijauhi. Berdasarkan hasil wawancara dengan KASUBAG UMUM persentase dari disiplin kerja pegawai pada Kantor Pelayanan Perbendaharaan Negara (KPPN) Pematangsiantar sebesar 25\% sangat baik, 60\% baik, dan $15 \%$ cukup baik. Fenomena disiplin kerja yang terjadi pada Kantor Pelayanan Perbendaharaan Negara (KPPN) Pematangsiantar berada pada dimensi menjalankan kewajiban. Hal ini ditunjukan masih terdapatnya pegawai yang melanggar aturan secara berulang-ulang terutama dalam hal penggunaan waktu kerja. Pada dimensi menjauhi larangan, sudah optimal hal ini disebabkan tingginya kesadaran pegawai untuk menjaga dan melindungi negeri ini.

Disiplin kerja pegawai juga di pengaruhi oleh etos kerja. Etos kerja merupakan suatu semangat kerja dan perilaku positif yang dimiliki oleh pegawai untuk mampu bekerja lebih baik guna memperoleh nilai tambah dalam kehidupan mereka. Dimensi pada etos kerja meliputi rahmat, amanah, panggilan, aktualisasi, ibadah, seni, kehormatan dan pelayanan. Fenomena etos kerja pada Kantor Pelayanan Perbendaharaan Negara (KPPN) Pematangsiantar pada dimensi pekerjaan sebagai amanah, panggilan dan ibadah. Hal ini ditunjukkan dari pegawai yang memiliki keyakinan untuk melakukan pekerjaan dengan baik, serta pegawai selalu patuh mengerjakan pekerjaan yang diberikan kepadanya.

Pada kerja sebagai aktualisasi, seni, kehormatan, dan pelayanan pegawai Kantor Pelayanan Perbendaharaan Negara (KPPN) Pematangsiantar selalu bekerja keras dalam mengerjakan tupoksinya dan mempunyai semangat yang tinggi dalam bekerja. Pegawai juga memberikan pelayanan yang baik sehingga dapat bekerja sama dengan rekan kerja dalam menyelesaikan pekerjaannya untuk kemajuan instansi. Sedangkan pada dimensi kerja adalah rahmat, masih belum optimal hal ini ditunjukkan masih terdapatnya sikap pegawai yang kurang tulus, dan ikhlas terhadap pekerjaan yang diembannya.

Kepuasan kerja merupakan refleksi dari perasaan pegawai terhadap pekerjaan yang dilakukan. Dimensi kepuasan kerja meliputi pekerjaan itu sendiri, gaji atau upah, kesempatan promosi, mutu pengawasan supervisi dan rekan kerja. Fenomena kepuasan kerja pegawai Kantor Pelayanan Perbendaharaan Negara (KPPN) Pematangsiantar dilihat dari pekerjaan itu sendiri yang diemban oleh pegawai, gaji atau upah yang diberikan sudah transparan karena telah diatur dalam peraturan pemerintah tentang gaji pegawai PNS, kesempatan promosi yang selalu diberikan kepada pegawai berprestasi, rekan kerja yang mampu bekerjasama dalam menuntaskan tugasnya. Pada dimensi mutu pengawasan supervisi masih belum optimal, hal ini dapat dilihat dari sikap pemimpin yang kurang memberikan arahan dan motivasi kepada bawahannya.

\section{Rumusan Masalah}

a. Bagaimana gambaran etos kerja, kepuasan kerja dan disiplin kerja pegawai pada Kantor Pelayanan Perbendaharaan Negara (KPPN) Pematangsiantar.

b. Bagaimana pengaruh etos kerja dan kepuasan kerja terhadap disiplin kerja pegawai pada Kantor Pelayanan Perbendaharaan Negara (KPPN) Pematangsiantar baik secara simultan maupun parsial.

\section{Tujuan Penelitian}

a. Untuk mengetahui gambaran etos kerja, kepuasan kerja dan disiplin kerja pegawai pada Kantor Pelayanan Perbendaharaan Negara (KPPN) Pematangsiantar.

b. Untuk mengetauhi pengaruh etos kerja dan kepuasan kerja terhadap disiplin kerja pegawai pada Kantor Pelayanan Perbendaharaan Negara (KPPN) Pematangsiantar baik secara simultan maupun parsial.

\section{Metode Penalitian}

Lokasi atau tempat penelitian ini dilakukan di Kantor Pelayanan Perbendahraan Negara (KKPN) Pematangsiantar yang berada di Jalan Brigjen Rajamin Purba, SH No.19 Pematangsiantar. Pada penelitian ini yang menjadi populasi adalah pegawai negeri sipil Kantor Pelayanan Perbendahraan Negara (KKPN) Pematangsiantar sebanyak 28 orang yang diambil dari data penjualan selama bulan JuliAgustus 2017. Seluruh pelanggan yang berjumlah 28 orang akan menjadi sampel sebagai responden untuk menjawab kuesioner yang penulis sebarkan, mengingat jumlahnya kurang dari 100 (seratus) orang dan ketersediaan waktu penulis serta untuk keakuratan hasil penelitian.

Adapun Desain penelitian yang digunakan dalam penulisan skripsi ini adalah Penelitian Kepustakaan (Library Research) dan Penelitian Lapangan (Field Research). Teknik pengumpulan data yang dilakukan penulis dalam penelitian ini adalah berupa Kuesioner, Wawancara dan Dokumentasi. Adapun jenis data yang digunakan dalam penelitian ini adalah jenis data kualitatif dan data kuantitatif. Hasil data yang diperoleh dari lapangan akan dianalisis secara deskriptif baik bersifat kualitatif dan kuantitatif.

\section{B. LANDASAN TEORI}

1. Manajemen Sumber Daya Manusia

Menurut Gomes (2003:4), berpendapat bahwa manajemen sumber daya manusia adalah pengembangan dan pemanfaatan personil (pegawai) bagi pencapaian yang efektif mengenai sasaran dan tujuan individu, organisasi masyarakat, nasional dan internasional.Sementara menurut Mathis dan John (2006:3), manajemen sumber daya manusia adalah rancangan sistem-sistem formal dalam sebuah organsasi untuk memastikan penggunaan bakat manusia secara efektif dan efisien guna mencapai tujuan-tujuan organisasional. Kemudian menurut Sutrisno (2011:5), manajemen sumber daya manusia merupakan bidang strategis dari organisasi yang 
harus dipandang sebagai perluasan dari pandangan tradisional untuk mengelola orang secara efektif dan untuk itu membutuhkan pengetahuan tentang perilaku manusia dan kemampuan mengelolanya.

Menurut Mondy (2008:4), ada tujuh fungsi manajemen sumber daya manusia, antara lain:

a. Penyediaan Staf, merupakan proses yang menjamin suatu organisasi untuk selalu memiliki jumlah karyawan yang tepat dengan keahliankeahlian yang memadai dalam pekerjaan yang tepat.

b. Pengembangan Sumber Daya Manusia, adalah fungsi MSDM utama yang tidak hanya tediri atas pelatihan dan pengembangan namun juga aktivitas-aktivitas perencanaan dan pengembangan karir individu, pengembangan organisasi, serta manajemen penilaian kinerja.

c. Kompensasi, suatu sistem kompensasi yang terencana matang memberi para pegawai imbalan-imbalan yang layak dan adil atas kontribusi mereka dalam mencapai tujuan-tujuan organisasi.

d. Keselamatan dan Kesehatan, adalah perlindungan bagi para pegawai dari luka-luka yang disebabkan oleh kecelakaan terkait dengan pekerjaan. Kesehatan adalah bebasnya pegawai dari sakit secara fisik atau emosi.

e. Hubungan Kepegawaian dan Perburuan, merupakan norma yang dapat diterima bagi banyak pemberi kerja, namun sebagian besar perusahaan dewasa ini lebih cenderung memilih lingkungan yang bebas serikat pekerja.

f. Riset Sumber Daya Manusia, merupakan kunci utama dalam mengembangkan produktivitas tenaga kerja meskipun riset ini bukan sebuah fungsi MSDM yang khusus.

g. Kesaling Terhubungan Fungsi-Fungsi MSDM, manajemen harus menyadari bahwa keputusankeputusan disatu area akan mempengaruhi area lainnya. Contohnya, suatu perusahaan yang berfokus merekrut calon-calon yang berkualitas terbaik namun mengabaikan pemberian kompensasi yang memuaskan akan membuang waktu, tenaga dan uang.

\section{Etos Kerja}

Menurut Sinamo (2005:151), etos kerja adalah seperangkat prilaku positif yang berakar pada keyakinan fundamental yang disertai komitmen total pada paradigma kerja integral. Kemudian menurut Asifudin (2004:26), etos kerja adalah sifat khusus tentang seorang individu atau sekelompok manusia yang memiliki sikap dan karakter, kebiasaan serta kepercayaan. Sedangkan Anoraga (2009:282), menyatakan bahwa etos kerja merupakan suatu pandangan dan sikap suatu bangsa atau umat terhadap kerja. Bila individu dalam komunitas memandang kerja sebagai suatu hal luhur bagi eksistensi manusia, maka etos kerjanya akan cenderung tinggi, sebaliknya jika etos kerja dengan sendirinya akan rendah, maka pandangan terhadap kerja sebagai sesuatu yang bernilai rendah bagi kehidupan.
Berdasarkan pendapat ahli diatas maka dapat ditarik kesimpulan bahwa etos kerja merupakan suatu tolak ukur atau pandangan mendasar untuk menjadi acuan dalam menilai kinerja, yang berguna untuk mempengaruhi seseorang dalam bekerja. Sehingga dapat meningkatkan kualitas hidup seseorang.

menurut Sinamo (2005:125), mengemukakan 8 etos kerja profesional yang diterapkan dengan baik dan mampu meningkatkan atau membangun etos kerja, 8 etos kerja itu antara lain:

a. Seseorang mau bekerja dengan tulus dan penuh syukur merupakan refleksi kerja adalah rahmat.

b. Seseorang memiliki komitmen untuk bekerja benar dan penuh tanggung jawab merupakan refleksi kerja adalah amanah

c. Seseorang bisa bekerja tuntas dan penuh integritas merupakan refleksi kerja adalah panggilan

d. Seseorang harus bekerja keras dan penuh semangat merupakan refleksi kerja adalah aktualisasi.

e. Seseorang memiliki komitmen untuk bekerja dengan serius dan penuh kecintaan merupakan refleksi kerja adalah ibadah

f. Seseorang akan bekerja cerdas dan penuh kreativitas merupakan refleksi kerja adalah seni

g. Seseorang akan bekerja tekun dan penuh keunggulan merupakan refleksi kerja adalah kehormatan.

h. Seseorang akan bekerja paripurna dan penuh kerendahan hati merupakan refleksi kerja adalah pelayanan.

\section{Kepuasan Kerja}

Menurut As'ad (2003:104), kepuasan kerja merupakan sikap umum yang merupakan hasil dari beberapa sikap khusus terhadap faktor-faktor pekerjaan, penyesuaian diri dan hubungan sosial individual dari luar kerja. Menurut Luthans (2005:243), kepuasan kerja adalah hasil dari persepsi pegawai mengenai seberapa baik pekerjaan mereka memberikan hal yang dinilai penting. Sedangkan menurut Priansa (2014:291), kepuasan kerja merupakan sekumpulan perasaan pegawai terhadap pekerjaannya, apakah senang/ suka atau tidak senang/ tidak suka sebagai hasil interaksi pegawai dengan lingkungan pekerjaannya atau sebagai persepsi sikap mental, juga sebagai hasil penilaian pegawai terhadap pekerjaannya.

Berdasarkan uraian pendapat para ahli diatas, penulis menyimpulkan bahwa kepuasan kerja adalah perasaan dari suatu keadaan yang dirasakan para pegawai baik menyenangkan atau tidak menyenangkan terhadap hasil kerja yang dicapai.

Menurut Luthans (2005:243), terdapat pengukuran yang standar terhadap kepuasan kerja, yang meliputi beberapa faktor yaitu :

a. Pekerjaan itu sendiri

Setiap pegawai lebih menyukai pekerjaan yang memberikan peluang kepada mereka untuk 
menggunakan keterampilan dan kemampuan yang dimiliki, yang mampu menawarkan suatu varietas tugas, kebebasan, umpan balik tentang seberapa baiknya mereka dalam melakukan hal tersebut. Karaktersistik tersebut membuat pekerjaan lebih menantang sacara mental. Riset mengenai keunikan pekerjaan, diketahui bahwa determinan utama dari kepuasan kerjaadalah sifat dari pekerjaan itu sendiri. Lima dari materi pekerjaan yang meliputi ragam keterampilan (skill variety), identitas pekerjaan (task identity), keberartian pekerjaan (task significance), otonomi (autonomi) dan umpan balik (payback). Dari setiap dimensi inti dari pekerjaan mencakup sejumlah aspek materi pekerjaan yang dapat dipengaruhi kepuasan kerja seseorang. Adapun kaitan masing-masing dimensi tersebut dengan semakin besarnya keragaman aktivitas pekerjaan yang dilakukan, seseorang akan merasa pekerjaan semakin berarti.

b. Gaji atau upah

Pegawai selalu menginginkan sistem pengajian yang sesuai dengan harapan mereka. Apabila pembayaran tersebut tampak adil berdasrkan pada permintaan pekerjaan, tingkat keterampilan individu, dan standar pembayaran masyarakat pada umumnya, maka kepuasan yang dihasilkan kan juga tinggi. Upah sebagai jumlah keseluruhan pengganti jasa yang telah dilakukan oleh tenaga kerja yang meliputi upah pokok dan tunjangan sosial lainnya. Gaji merupakan salah satu karakteristik pekerjaan yang menjadi ukuran ada tidaknya kepuasan kerja, dalam artian ada tidaknya pemeberian pada gaji tersebut.

c. Kesempatan promosi

Promosi merupakan perpindahan dari satu jabatan ke jabatan yang lain dimana jabatan tersebut memiliki tanggung jawab yang lebih tinggi. Hal ini memberikan nilai tersendiri bagi pegawai, karena merupakan bukti pengakuan terhadap prestasi kerja yang telah dicapai oleh pegawai. Promosi juga memberikan kesempatan untuk pertumbuhan pribadi, untuk lebih bertanggungjawab dan meningkatkan status sosial. Oleh karena itu, salah satu kepuasan kerja terhadap pekerjaan dapat dirasakan melalui ketepatan dan kesempatan promosi yang diberikan oleh perusahaan.

d. Mutu pengawasan supervisi

Kegiatan pengawasan merupakan suatu proses dimana seorang manajer dapat memastikan bahwa kegiatan yang dilakukan oleh pegawai sesuai dengan apa yang direncanakan sebelumnya. Proses pengawasan mencatat perkembangan pekerjaan yang dilakukan oleh pegawai sehingga memungkinkan manajer untuk dapat mendeteksi adanya penyimpangan dari apa yang telah direncanakan dengan hasil saat ini, dan kemudian dapat dilakukan tindakan pembetulan untuk mengatasinya. Hal penting yang menentukan selain kepuasan kerja itu sendiri adalah perilaku pengawas.Sebagian besar dari studi yang telah dilakukan mewujudkan hasil bahwa pegawai akan lebih puas dengan pemimpin yang lebih bijaksana, memperhatikan kemajuan, perkembangan dan prestasi kerja dari pegawai.
Rekan kerja merupakan bagian dari perwujudan salah satu faktor motivasi, yaitu kebutuhan akan hubungan (relatedness needs), dimana penekanan ada pentingnya hubungan antar individu (interpesonal relationship) dan bermasyarakat (social relationship). Pada dasarnya seorang pegawai juga menginginkan adanya perhatian dari rkan kerjanya, sehingga pekerjaan juga mengisi kebutuhan pegawai akan interaksi sosial, sehingga pada saat seorang pegawai memiliki rekan kerja yang saling mendukung dan bersahabat, maka akan meningkatkan kepuasan kerja mereka.

\section{Disiplin Kerja}

Menurut Saydam (2000:284), bahwa disiplin adalah sikap kesediaan dan kerelaan sesorang untuk memenuhi dan menaati segala norma-norma dan peraturan yang berlaku disekitarnya. Menurut Peraturan Pemerintah Nomor 53 tahun 2010, disiplin pegawai negeri sipil (PNS) adalah kesanggupan pegawai negaeri sipil (PNS) untuk menaati kewajiban dan menghindari larangan yang ditentukan dalam peraturan perundang-undangan dan/atau peraturan kedinasan yang apabila tidak ditaati atau dilanggar dijatuhi hukuman disiplin. Sedangkan menurut Zainal (2015:599), disiplin kerja adalah suatu alat yang digunakan para manajer untuk berkomunikasi dengan pegawai agar mereka bersedia untuk mengubah suatu prilaku serta sebagai suatu upaya untuk meningkatkan kesadaraan dan kesediaan seseorang mentaati semua peraturan perusahaan dan norma-norma sosial yang berlaku.

Berdasarkan pendapat para ahli, maka penulis dapat menyimpulkan bahwa disiplin adalah suatu tindakan yang bersifat memaksa seseorang untuk mengubah dan memperbaiki sikap atau perilaku, melalui tindakan disipliner positif dalam meningkakan kesadaran untuk menaati peraturan dan norma-norma yang berlaku didalam sebuah organisasi.

Peraturan Pemerintah Republik Indonesia Nomor 53 Tahun 2010 Tentang Disiplin Pegawai Negeri Sipil, Kewajiban serta larangan tersebut adalah sebagai berikut:

1) Setiap pegawai negeri sipil (PNS) wajib:

a) mengucapkan sumpah/ janji PNS

b) mengucapkan sumpah/ janji jabatan

c) setia dan taat sepenuhnya kepada Pancasila, Undang-Undang Dasar Negara Republik Indonesia Tahun 1945, Negara Kesatuan Republik Indonesia, dan Pemerintah

d) Menaati segala ketentuan peraturan perundang-undangan

e) Melaksanakan tugas kedinasan yang dipercayakan kepada PNS dengan penuh pengabdian, kesadaran, dan tanggung jawab

f) Menjunjung tinggi kehormatan negara, Pemerintah, dan martabat PNS

g) Mengutamakan kepentingan negara daripada kepentingan sendiri, seseorang dan atau golongan e. Rekan kerja 
h) Memegang rahasia jabatan yang menurut sifatnya atau menurut perintah harus dirahasiakan

i) Bekerja dengan jujur, tertib, cermat, dan bersemangat untuk kepentingan negara

j) Melaporkan dengan segera kepada atasannya apabila mengetahui ada hal yang dapat membahayakan atau merugikan negara atau Pemerintah terutama di bidang keamanan, keuangan, dan materiil

k) Masuk kerja dan menaati ketentuan jam kerja

1) Mencapai sasaran kerja pegawai yang ditetapkan

m) Menggunakan dan memelihara barang-barang milik negara dengan sebaikbaiknya

n) Memberikan pelayanan sebaik-baiknya kepada masyarakat

o) Membimbing bawahan dalam melaksanakan tugas

p) Memberikan kesempatan kepada bawahan untuk mengembangkan karier

q) Menaati peraturan kedinasan yang ditetapkan oleh pejabat yang berwenang.

2) Setiap pegawai negeri sipil (PNS) dilarang:

a) Menyalahgunakan wewenang

b) Menjadi perantara untuk mendapatkan keuntungan pribadi dan/atau orang lain dengan menggunakan kewenangan orang lain

c) Tanpa izin Pemerintah menjadi pegawai atau bekerja untuk negara lain dan/atau lembaga atau organisasi lnternasional

d) Bekerja pada perusahaan asing, konsultan asing, atau lembaga swadaya masyarakat asing

e) Memiliki, menjual, membeli, menggadaikan, menyewakan, atau meminjamkan barangbarang baik bergerak atau tidak bergerak, dokumen atau surat berharga milik negara secara tidak sah

f) Melakukan kegiatan bersama dengan atasan, teman sejawat, bawahan, atau orang lain di dalam maupun diluar lingkungan kerjanya dengan tujuan untuk keuntungan pribadi, golongan, atau pihak lain, yang secara langsung atau tidak langsung merugikan negara

g) Memberi atau menyanggupi akan memberi sesuatu kepada siapapun baik secara langsung atau tidak langsung dan dengan dalih apapun untuk diangkat dalam jabatan

h) Menerima hadiah atau suatu pemberian apa saja dari siapapun juga yang berhubungan dengan jabatan dan/atau pekerjaannya

i) Bertindak sewenang-wenang terhadap bawahannya

j) Melakukan suatu tindakan atau tidak melakukan suatu tindakan yang dapat menghalangi atau mempersulit salah satu pihak yang dilayani sehingga mengakibatkan kerugian bagi yang dilayani

k) Menghalangi berjalannya tugas kedinasan

1) Memberikan dukungan kepada calon Presiden/ Wakil Presiden, Dewan Perwakilan
Rakyat, Dewan Perwakilan Daerah, atau Dewan Perwakilan Rakyat Daerah dengan cara:

(1) Ikut serta sebagai pelaksana kampanye

(2) Menjadi peserta kampanye dengan menggunakan atribut partai atau atribut PNS

(3) Sebagai peserta kampanye dengan mengerahkan PNS lain; dan/atau

(4) Sebagai peserta kampanye dengan menggunakan fasilitas negara.

m) Memberikan dukungan kepada calon PresidenlVVakil Presiden dengan cara:

(1) Membuat keputusan dan/atau tindakan yang menguntungkan atau merugikan salah satu pasangan calon selama masa kampanye

(2) Mengadakan kegiatan yang mengarah kepada keberpihakan terhadap pasangan calon yang menjadi peserta pemilu sebelum, selama, dan sesudah masa kampanye meliputi pertemuan, ajakan, himbauan, seruan, atau pemberian barang kepada PNS dalam lingkungan unit kerjanya, anggota keluarga, dan masyarakat.

n) Memberikan dukungan kepada calon anggota Dewan Perwakilan Daerah atau calon Kepala Daerah/ Wakil Daerah dengan cara memberikan surat dukungan disertai foto kopi Kartu Tanda Penduduk atau Surat Keterangan Tanda Penduduk sesuai peraturan perundangundangan

o) Memberikan dukungan kepada calon Kepala Daerah/ Wakil Kepala Daerah, dengan cara:

(1) Terlibat dalam kegiatan kampanye untuk mendukung calon Kepala Daerah/ Wakil Kepala Daerah

(2) Menggunakan fasilitas yang terkait dengan jabatan dalam kegiatan kampanye

(3) Membuat keputusan dan/ atau tindakan yang menguntungkan atau merugikan salah satu pasangan calon selama masa kampanye

(4) Mengadakan kegiatan yang mengarah kepada keberpihakan terhadap pasangan calon yang menjadi peserta pemilu sebelum, selama, dan sesudah masa kampanye meliputi pertemuan, ajakan, himbauan, seruan, atau pemberian barang kepada PNS dalam lingkungan unit kerjanya, anggota keluarga, dan masyarakat.

5.Pengaruh Etos Kerja dan Kepuasan Kerja Terhadap Disiplin Kerja Pegawai

Disiplin kerja pegawai merupakan perwujudan sikap dari pegawai dengan tulus, ikhlas, dan rasa sadar dalam menaati peraturan dan kebijaksanaan kantor dalam upaya pencapaian tujuan kantor. Ketika seorang disiplin dalam melaksanakan 
pekerjaannya, ia akan memaksimalkan kemampuan yang dimiliki untuk meyelesaikan tugasnya.

Menurut Sinamo (2005:124), setiap manusia memiliki spirit (roh) keberhasilan, roh inilah yang menjelma perilaku yang khas seperti kerja keras, disiplin dalam bekerja, teliti, tekun, integritas, rasional, bertanggung jawab yang menjadi motivasi murni untuk meraih dan menikmati keberhasilan. Ini menunjukkan bahwa pegaawai yang memiliki etos kerja yang tinggi akan tercermin dari perilakunya, seperti suka bekerja keras, bersikap adil, hormat terhadap rekan-rekan dan sebagainya. Hal ini akan meningkatkan disiplin kerja pegawai.

Menurut Mathis dan John (2011:46), menyatakan bahwa kepuasan kerja sangat berperan dalam membentuk kedisiplinan, komitmen dan kinerja pegawai yang kemudian berpengaruh terhadap kualitas layanan dalam usaha untuk mencapai tujuan bersama. Hal ini menunjukkan bahwa menigkatnya kepuasan kerja yang oleh kehadiran pegawai yang tepat waktu, tidak pernah pulang sebelum jam kerja selesai, mampu menyelesaikan pekerjaannya tepat waktu, mampu menggunakan waktu secara efektif, bekerja dengan kualitas baik mengikuti prosedur dan intruksi dari atasan, hadir dalam setiap rapat dan berpenampilan sopan dan berpakaian sesuai aturan yang ada maka dapat menyebabkan disiplin kerja pegawai semakin meningkat.

Berdasarkan uraian diatas, maka penulis menyimpulkan bahwa etos kerja dan kepuasan kerja berhubungan erat dengan disiplin kerja pegawai. Dengan adanya etos kerja yang tinggi dan kepuasan kerja yang tinggi hal ini akan dapat meningkatkan disiplin kerja pegawai.

\section{PEMBAHASAN}

1. Analisa

\section{a. Deskriptif Kualitatif}

Analisis deskriptif kualitatif dimaksudkan untuk mendapatkan gambaran atau deskripsi mengenai pengaruh etos kerja dan kepuasan kerja terhadap disiplin kerja pegawai Kantor Pelayanan Perbendaharaan Negara (KPPN) Pematangsiantar. Sesudah pengujian data, maka langkah selanjutnya peneliti melakukan pengkajian analisis kualitatif sebagai gambaran fenomena dari variabel penelitian pada saat sekarang ini. Setelah kuesioner diolah, maka nilai-nilai jawaban dari setiap data responden dibagi menjadi beberapa kelas interval.

Adapun pendapatan kriteria nilai rata-rata jawaban dari responden tersebut dimasukkan kedalam kelas-kelas interval dimana penelitian intervalnya memakai rumus sebagai berikut:

$$
\underline{\text { Nilai Tertinggi-Nilai Terendah }}
$$

Interval Kelas $=$ Jumlah Kelas

Interval Kelas $=\frac{5-1}{5}=\frac{4}{5}=$

Dari rumus di atas dapat diperoleh interval kelas 0,8 sehingga berlaku ketentuan mengenai jawaban responden dengan hasil sebagai berikut:

Tabel 1

Nilai Interval dan Kategori Jawaban Responden
\begin{tabular}{|c|c|}
\hline $\begin{array}{c}\text { Nilai } \\
\text { Interval }\end{array}$ & Kategori \\
$1,00-1,80$ & $\begin{array}{c}\text { Sangat Tidak Baik (STB) / Sangat } \\
\text { Rendah (SR) / Sangat Tidak Puas } \\
\text { (STP) }\end{array}$ \\
\hline $1,81-2,60$ & $\begin{array}{c}\text { Tidak Baik (TB) / Rendah (R)/ } \\
\text { Tidak Puas (TP) }\end{array}$ \\
\hline $2,61-3,40$ & $\begin{array}{c}\text { Cukup Baik (CB) / Cukup Tinggi } \\
\text { (CT) / Cukup Puas (CP) }\end{array}$ \\
\hline $3,41-4,20$ & Baik (B) / Tinggi (T) / Puas (P) \\
\hline $4,21-5,00$ & $\begin{array}{c}\text { Sangat Baik (SB) / Sangat Tinggi } \\
\text { (ST) / Sangat Puas (SP) }\end{array}$ \\
\hline
\end{tabular}

Sumber: hasil pengolahan data, 2017

\section{Gambaran Etos Kerja Pada Kantor Pelayanan Perbendaharaan Negara (KPPN) Pematangsiantar}

Etos kerja adalah seperangkat sikap atau pandangan mendasar yang dipegang pegawai untuk menilai bekerja sebagai suatu hal yang positif bagi peningkatan kualitas kehidupan mereka. Pada Kantor Pelayanan Perbendaharaan Negara (KPPN) Pematangsiantar, etos kerja menggunakan delapan dimensi dalam meningkatkan disiplin kerja pegawai antara lain dimensi kerja adalah rahmat, amanah, panggilan, aktualisasi, ibadah, seni, kehormatan, pelayanan.Terkait dengan kerja adalah rahmat, sehingga pegawai mau bekerja dengan tulus dan penuh rasa syukur. Kerja adalah Amanah, sehingga pegawai memiliki komitmen untuk bekerja benar dan penuh tanggung jawab. Kerja adalah Panggilan, sehingga pegawai bisa bekerja dengan tuntas dan penuh integritas. Kerja adalah Aktualisasi, pegawai harus bekerja keras dan penuh integritas.Dimensi Kerja adalah Ibadah, sehingga pegawai memiliki komitmen untuk bekerja dengan serius. Kerja adalah Seni, sehingga pegawai akan bekerja cerdas dan penuh kreativitas. Kerja adalah Kehormatan, sehingga pegawai akan bekerja tekun dan penuh keunggulan. Kerja adalah pelayanan, sehingga pegawai bekerja paripurna dan penuh kerendahan hati.

Berdasarkan hasil analisis deskriptif kualitatif menegenai etos kerja berdasarkan dimensi kerja adalah rahmat, amanah, panggilan, aktulisasi, ibadah, seni, kehormatan, pelayanan memperoleh rata-rata jawaban keseluruhan 3,89 dengan kriteria tinggi. Kemudian nilai rata-rata tertinggi sebesar 4,18 dengan kriteria jawaban tinggi pada dimensi kerja adalah panggilan dengan indikator pegawai memiliki panggilan untuk mau bekerja dengan penuh integritas dan pada dimensi kerja adalah seni dengan indikator pegawai memiliki seni dalam mewujudkan cita-cita. Sedangkan nilai rata-rata terendah sebesar 3,21 dengan kriteria jawaban cukup tinggi pada indikator pegawai memiliki rahmat untuk patuh dalam bekerja. 


\section{Gambaran Kepuasan Kerja Pada Kantor Pelayanan Perbendaharaan Negara (KPPN) Pematangsiantar}

Kepuasan kerja adalah suatu keadaan yang dirasakan para pegawai terhadap keadaan suatu kondisi pekerjaannya dan lingkungan kerja yang sesuai dengan keinginan pegawai dari peraturan yang berlaku pada kantor tersebut. Kantor Pelayanan Perbendaharaan Negara (KPPN) Pematangsiantar menciptakan kepuasan kerja kepada pegawainya sebagai salah satu bentuk untuk mempertahankan serta memberikan kenyamanan kepada pegawainya. Dalam menciptakan kepuasan kerja bagi pegawainya Kantor Pelayanan Perbendaharaan Negara (KPPN) Pematangsiantar memperhatikan beberapa faktor yaitu pekerjaan itu sendiri, gaji atau upah, kesempatan promosi, dan rekan kerja. Pekerjaan itu sendiri, yaitu isi pekerjaan yang dilakukan seseorang apakah memiliki elemen yang memuaskan. Gaji atau upah adalah imbalan balas jasa yang diterima para pegawai dipandang sebagai sesuatu hal yang adil dalam organisasi. Kesempatan promosi, yaitu kemungkinan sesorang dapat berkembang melalui kenaikan jabatan. Mutu pengawasan supervisi adalah seseorang yang senantiasa memberi perintah atau petunjuk dalam pelaksanaan kerja, cara-cara atasan dapat tidak menyenangkan dan hal ini dapat mempengaruhi kepuasan kerja. Rekan kerja adalah kepada siapa sesorang senantiasa berinteraksi dalam pelaksanaan pekerjaannya.

Berdasarkan hasil analisis deskriptif kualitatif tentang kepuasan kerja berdasarkan dimensi pekerjaan itu sendiri, gaji atau upah, kesempatan promosi, mutu pengawasan supervisi, rekan kerja memperoleh rata-rata 3,82 dengan kriteria jawaban puas. Nilai rata-rata tertinggi sebesar 4,18 dengan kriteria jawaban puas pada dimensi rekan kerja dengan indikator dukungan dari rekan kerja. Sedangkan nilai rata-rata terendah sebesar 3,29 dengan kriteria jawaban cukup puas pada dimensi mutu pengawasan supervisi dengan indikator tingkat perhatian yang diberikan atasan.

3. Gambaran Disiplin Kerja Pegawai Pada Kantor Pelayanan Perbendahraan Negara (KPPN) Pematangsiantar.

Disiplin kerja merupakan salah satu aspek yang harus dimiliki setiap pegawai. Penerapan disiplin pegawai di suatu organisasi akan menciptakan keteratuaran dalam bekerja serta tertib dalam segala hal, jika pegawai dalam suatu organisasi memilki tingkat kedisiplinan yang baik dalam bekerja, maka tugas-tugas yang dibebankan kepadanya akan memilki kualitas yang baik. Pegawai yang bekerja di Kantor Pelayanan Perbendaharaan Negara (KPPN) Pematangsiantar merupakan pegawai negeri sipil (PNS). Sehingga, para pegawai harus menjalankan kewajiban serta menjauhi larangan yang ada berdasarkan Peraturan Pemerintah Nomor 53 Tahun 2010 Tentang Disiplin Pegawai Negeri Sipil. Pegawai negeri sipil memiliki kewajiban yang harus dijalankan untuk menjaga kedisiplinan tersebut. Berdasarkan Peraturan
Pemerintah Nomor 53 Tahun 2010 Tentang Disiplin Pegawai Negeri Sipil, kewajiban yang harus dijalankan oleh pegawai negeri sipil, seperti mengucapkan sumpah PNS, mengucapkan sumpah jabatan, setia dan taat pada Pancasila, UndangUndang Dasar Tahun 1945, negara Republik Indonesia, mejalankan tugas kedinasan, menjunjung tinggi kehormatan negara, bekerja dengan jujur, dan kewajiban-kewajiban lainnya yang harus dijalankan pegawai. Sedangkan hal-hal yang dilarang untuk dilakukan para pegawai negeri sipil, seperti menyalahgunakan wewenang, menjadi perantara untuk mendapatkan keuntungan pribadi, bekerja untuk negara lain atau perusahaan asing, memiliki atau menjual barang-barang milik negara secara tidak sah, dan larangan-larangan lain yang telah dibuat oleh pemerintah agar tercipta kedisiplinan yang tinggi pada diri pegawai negeri sipil dan untuk menjauhkan instansi atau negara dari masalah.

Berdasarkan hasil analisis deskriptif kualitatif tentang disiplin kerja pegawai berdasarkan dimensi menjalankan kewajiban dan menjauhi larangan memperoleh nilai rata-rata 3,86 dengan kriteria baik. Kemudian nilai rata-rata tertinggi sebesar 4,21 dengan kriteria sangat baik pada dimensi menjauhi larangan dengan indikator tanpa izin pemerintah bekerja untuk negara lain. Sedangkan nilai rata-rata terendah sebesar 2,96 dengan kriteria jawaban cukup baik pada dimensi menjalankan kewajiban dengan indikator menaati peraturan kedinasan.

\section{b. Deskriptif Kuantitatif}

\section{1) Analisa Regresi Linear Berganda}

Penelitian ini memiliki tujuan untuk menganalisis pengaruh etos kerja dan kepuasan kerja terhadap disiplin kerja pegawai pada Kantor Pelayanan Perbendaharaan Negara (KPPN) Pematangsiantar. Analisis regresi linier berganda digunakan untuk mengetahui pengaruh variabel bebas $(\mathrm{X})$ dan variabel terikat $(\mathrm{Y})$, dimana $\mathrm{X}_{1}$ adalah etos kerja, $\mathrm{X}_{2}$ kepuasan kerja, dan $\mathrm{Y}$ adalah disiplin kerja pegawai. Maka dilakukan perhitungan menggunakan program aplikasi SPSS untuk memperoleh nilai a dan $\mathrm{b}$ dengan notasi sebagai berikut: $\hat{Y}=b_{0}+b_{1} X_{1}+b_{2} X_{2}$.

Tabel 2

Regresi Linier Berganda Coefficients $^{a}$

\begin{tabular}{|c|c|c|c|c|}
\hline & \multirow[t]{2}{*}{ Model } & \multicolumn{2}{|c|}{$\begin{array}{c}\text { Unstandardized } \\
\text { Coefficients }\end{array}$} & \multirow{2}{*}{$\begin{array}{c}\begin{array}{c}\text { Standardized } \\
\text { Coefficients }\end{array} \\
\text { Beta }\end{array}$} \\
\hline & & $\mathrm{B}$ & Std. Error & \\
\hline & (Constant) & 35,010 & 14,398 & \\
\hline & Etos Kerja & ,490 & 134 & ,482 \\
\hline & $\begin{array}{l}\text { Kepuasan } \\
\text { Kerja }\end{array}$ & ,763 & 209 & 481 \\
\hline
\end{tabular}

a. Dependent Variable: Disiplin Kerja Pegawai

Sumber: hasil perhitungan SPSS Statistics versi

$$
\text { 21, } 2017
$$

Dari hasil analisis regresi dengan SPSS pada tabel 2 diatas diperoleh koefisien regresi $b_{1}$ sebesar 0,490 dan $b_{2}$ sebesar 0,763 sehingga dapat diketahui persamaan regresi yang diperoleh adalah : $\hat{\mathrm{Y}}=$ $35,010+0,490 \mathrm{X}_{1}+0,763 \mathrm{X}_{2}$, artinya terdapat 
pengaruh yang positif antara variabel etos kerja $\left(\mathrm{X}_{1}\right)$ dan variabel kepuasan kerja $\left(\mathrm{X}_{2}\right)$ terhadap disiplin kerja pegawai (Y) pada Kantor Pelayanan Perbendaharaan Negara (KPPN) Pematangsiantar.

\section{2) Korelasi dan Koefisien Determinasi}

Untuk menghitung kekuatan hubungan etos kerja dan kepuasan kerja terhadap disiplin kerja pegawai dilakukan analisi korelasi, berupa derajat atau kedalaman hubungan fungsional yang menjelaskan hubungan antar perubah, dinyatakan dengan koefisien korelasi yang disimbolkan dengan r. Nilai $r$ dapat dilihat melalui tabel berikut:

\section{Tabel 3}

Korelasi dan Koefisien Determinasi Model Summary

\begin{tabular}{|c|c|c|c|c|}
\hline Model & $\mathbf{r}$ & $\begin{array}{c}R \\
\text { Squar } \\
e\end{array}$ & $\begin{array}{l}\text { Adjusted } \\
\text { R Square }\end{array}$ & $\begin{array}{l}\text { Std. Error of the } \\
\text { Estimate }\end{array}$ \\
\hline 1 &, $781^{\mathrm{a}}$ & ,610 & ,579 & 7,775 \\
\hline
\end{tabular}

Sumber : hasil perhitungan SPSS Statistic versi 21 2017

Dari tabel 3 diatas, didapat $r=0,781$ yang artinya terdapat hubungan yang kuat dan positif antara etos kerja dan kepuasan kerja terhadap disiplin kerja pegawai pada Kantor Pelayanan Perbendaharaan Negara (KPPN) Pematangsiantar. Selanjutnya diperoleh koefisien determinasi $\mathrm{R}$ square 0,610 artinya baik tidaknya disiplin kerja pegawai (Y) pada Kantor Pelayanan Perbendaharaan Negara (KPPN) Pematangsiantar sebesar 61\% dapat dijelaskan oleh etos kerja $\left(\mathrm{X}_{1}\right)$ dan kepuasan kerja $\left(\mathrm{X}_{2}\right)$, selebihnya $39 \%$ dijelaskan oleh faktor-faktor lain seperti motivasi, kompensasi, lingkungan kerja, kinerja, komunikasi dan faktor-faktor lain yang tidak dibahas dalam penelitian ini.

\section{3) Uji Hipotesis}

a) Uji Simultan (Uji F)

Uji F digunakan untuk mengetahui apakah variabel bebas (etos kerja dan kepuasan kerja) berpengaruh terhadap variabel terikat (disiplin kerja pegawai) secara bersama-sama atau simultan. Pengujian ini dilakukan untuk membandingkan antara $F_{\text {hitung }}$ dan $F_{\text {tabel }}$ pada taraf signifikansi sebesar $5 \%$ atau $\alpha=0,05$ dengan menggunakan program aplikasi SPSS, dapat dilihat dari tabel berikut:

\section{Tabel 4}

Perkiraan Nilai F hitung ANOVA

\begin{tabular}{|c|c|c|c|c|c|c|}
\hline & Model & $\begin{array}{l}\text { Sum of } \\
\text { Squares }\end{array}$ & Df & $\begin{array}{c}\text { Mean } \\
\text { Square }\end{array}$ & $\mathbf{F}$ & Sig. \\
\hline \multirow{3}{*}{1} & $\begin{array}{l}\text { Regress } \\
\text { ion }\end{array}$ & 2361,852 & 2 & 1180,926 & $\begin{array}{r}19,53 \\
7\end{array}$ &, $000^{b}$ \\
\hline & $\begin{array}{l}\text { Residua } \\
l\end{array}$ & 1511,148 & 25 & 60,446 & & \\
\hline & Total & 3873,000 & 27 & & & \\
\hline
\end{tabular}

Sumber : hasil perhitungan SPSS Statistic versi 21, 2017

Berdasarkan tabel 4 diatas, diperoleh nilai $F_{\text {hitung }}$ sebesar $19,537>F_{\text {tabel }}(0,05 ; 2$ VS 25) sebesar 3,39 atau dengan taraf signifikan $0,000<\alpha 0,05$, maka $\mathrm{H}_{0}$ ditolak, artinya etos kerja dan kepuasan kerja berpengaruh positif dan signifikan terhadap disiplin kerja pegawai pada Kantor Pelayanan Perbendaharaan Negara (KPPN) Pematangsiantar secara simultan.

\section{b) Uji Parsial (Uji t)}

Untuk menghasilkan suatu kesimpulan yang valid, maka harus dilakukan uji hipotesis (uji t). Dari hasil perhitungan koefisien korelasi diketahui bahwa gaya kepemimpinan, pengembangan karir dan kepuasan kerja karyawan sangat berhubungan, untuk menguji kebenarannya maka dilkuakan pengujian hipotesis dengan menggunakan program SPSS, dapat dilihat pada tabel berikut ini:

\section{Tabel 5}

Perkiraan Nilai thitung

Coefficients ${ }^{a}$

\begin{tabular}{|c|c|c|}
\hline Model & $\mathbf{t}$ & Sig. \\
\hline $\begin{array}{ll} & \text { (Constant) } \\
1 & \text { Etos Kerja }\left(\mathrm{X}_{1}\right) \\
& \text { Kepuasan Kerja }\left(\mathrm{X}_{2}\right)\end{array}$ & $\begin{array}{l}2,432 \\
3,660 \\
3,652\end{array}$ & $\begin{array}{l}, 023 \\
, 001 \\
, 001\end{array}$ \\
\hline
\end{tabular}

a. Dependent Variable: Disiplin Kerja Pegawai

Sumber : hasil perhitungan SPSS Statistics 21, 2017

Dari tabel 5 diatas, dapat dilihat nilai $t_{\text {hitung }}$ pada variabel Etos Kerja $\left(\mathrm{X}_{1}\right)$ sebesar 3,660 $>\mathrm{t}_{\text {tabel }}$ dengan $\mathrm{df}=\mathrm{n}-\mathrm{k}-1(28-2-1=25)$ sebesar 2,05954 atau dengan taraf signifikan $0,001<\alpha 0,05$, maka $\mathrm{H}_{0}$ ditolak, artinya etos kerja berpengaruh positif dan signifikan terhadap disiplin kerja pegawai pada Kantor Pelayanan Perbendaharaan Negara (KPPN) Pematangsiantar secara parsial. Sedangkan $t_{\text {hitung }}$ pada variabel kepuasan kerja $\left(\mathrm{X}_{2}\right)$ sebesar 3,652 $>\mathrm{t}_{\text {tabel }}$ dengan $\mathrm{df}=\mathrm{n}-\mathrm{k}-1 \quad(28-2-1=25)$ sebesar 2,05954, atau dengan taraf signifikan $0,001<\alpha 0,05$, maka $\mathrm{H}_{0}$ ditolak, artinya kepuasan kerja berpengaruh positif dan signifikan terhadap disiplin kerja pegawai pada Kantor Pelayanan Perbendaharaan Negara (KPPN) Pematangsiantar secara parsial.

\section{Evaluasi}

\section{a. Etos Kerja Pada Kantor Pelayanan \\ Perbendaharaan Negara (KPPN) \\ Pematangsiantar}

Berdasarkan hasil rekapitulasi penelitian, maka diperoleh hasil penelitian yang menyatakan bahwa etos kerja pada Kantor Pelayanan Perbendaharaan Negara (KPPN) Pematangsiantar dapat dikatakan baik, hal ini dapat dibuktikan dari hasil kuesioner yang dibagikan kepada responden yang secara keseluruhan diperoleh nilai rata-rata 3,89 dengan kriteria jawaban tinggi.

Pada dimensi kerja adalah rahmat dengan indikator pegawai memiliki rahmat untuk patuh dalam bekerja berada pada rata-rata 3,21 dengan kriteria jawaban cukup tinggi. Cara meningkatkan 
hal ini pegawai sebaiknya pegawai lebih mengefektivkan prosedur atau aturan yang berlaku di dalam kantor. Pada dimensi kerja adalah amanah dengan indikator pegawai memilki amanah untuk bekerja dengan benar berada pada rata-rata 3,86 dengan kriteria nilai jawaban tinggi, cara meningkatkannya pegawai sebaiknya benar-benar, jujur serta teliti dalam menyelesaikan tugasnya. Pada dimensi kerja adalah aktualisasi dengan indikator pegawai memilki aktualisasi untuk mau bekerja keras berada pada rata-rata 3,46 dengan kriteria jawaban tinggi, cara meningkatkannya pegawai sebaiknya mengeksplorasi kemampuan yang dimilikinya.

Pada dimensi kerja adalah ibadah untuk indikator pegawai memiliki ibadah untuk mau bekerja dengan serius berada pada rata-rata 3,50 dengan kriteria jawaban tinggi, cara meningkatkannya pegawai sebaiknya bersungguhsungguh dalam bekerja serta memandang suatu pekerjan adalah hal yang wajib dilakukan. Pada dimensi kerja adalah seni dengan indikator pegawai memiliki seni untuk bekerja dengan cerdas berada pada rata-rata 3,86 dengan kriteria jawaban tinggi, cara meningkatkannya pegawai sebaiknya berpikir secara kreatif dan inovatif. Pada dimensi kerja adalah kehormatan dengan indikator pegawai memiliki kehormatan untuk mau bekerja dengan tekun berada pada rata-rata 3,54 dengan kriteria jawaban tinggi, cara meningkatkannya pegawai sebaiknya dapat bekerja sesuai dengan prosedur yang berlaku di kantor tersebut. Untuk indikator pegawai memilki kehormatan dalam meningkatkan wibawa berada pada rata-rata 3,54 dengan kriteria jawaban tinggi, cara meningkatkannya pegawai sebaiknya memiliki sikap yang tegas dan penuh integritas. Pada dimensi kerja adalah pelayanan dengan indikator sikap positif pegawai dalam menilai bekerja sebagai bentuk pelayanan berada pada rata-rata 3,86 dengan kriteria jawaban tinggi, cara meningkatkanya pegawai sebaiknya lebih ramah dan sopan dalam memberikan pelayanan kepada masyarakat.

Dalam hal ini dapat diambil kesimpulan bahwa etos kerja pegawai Kantor Pelayanan Perbendahraan Negara (KPPN) Pematangsiantar sudah dikategorikan tinggi. Walaupun sudah dikategorikan tinggi, pegawai sebaiknya tetap meningkatkan etos kerjanya seperti suka bekerja keras, tidak membuang-buang waktu selama jam kerja, mau bekerjasama, dan hormat kepada rekan kerja dan sebagainya. Hal ini akan berkonstribusi untuk meningkatkan perkembangan kantor.

\section{b. Kepuasan Kerja Pada Kantor Pelayanan Perbendaharaan Negara (KPPN) \\ Pematangsiantar}

Berdasarkan hasil rekapitulasi penelitian, maka diperoleh hasil penelitian yang menyatakan bahwa kepuasan kerja pada Kantor Pelayanan Perbendaharaan Negara (KPPN) Pematangsiantar dapat dikatakan puas, hal ini dapat dilihat dari hasil kuesioner yang dibagikan kepada responden yang secara keseluruhan diperoleh nilai rata-rata 3,82 dengan kriteria jawaban puas.

Pada dimensi pekerjaan itu sendiri dengan indikator kenyamanan dalam bekerja berada pada rata-rata 3,75 dengan kriteria jawaban puas, cara meningkatkannya hendaknya kantor menciptakan tempat dan suasana yang kondusif agar kenyamanan pegawai bisa terwujud. Untuk indikator pekerjaan yang diberikan berada pada rata-rata 3,75 dengan kriteria jawaban puas, cara meningkatkannya dengan dilakukannya rotasi atau mutasi pekerjaan yang sesuai dengan keahlian pegawai agar pegawai mendapat tantangan dan ilmu yang baru. Untuk indikator sikap pegawai terhadap pekerjaannya berada pada rata-rata 3,75 dengan ktriteria jawaban puas, cara meningkatkannya pegawai sebaiknya bersikap positif terhadap pekerjaannya, agar pekerjaan yang dikerjakannya dapat terselesaikan dengan baik.

Pada dimensi gaji atau upah dengan indikator gaji sesuai pekerjaan berada pada rata-rata 3,71 dengan kriteria jawaban puas, cara meningkatkannya dengan cara menaikkan golongan atau pangkatnya yang telah diatur didalam PP No. 30 tahun 2015 , dimana pegawai yang naik golongan akan menigkatkan gaji atau upahnya. Hal ini juga dapat memotivasi pegawai yang lainnya.

Pada dimensi kesempatan promosi dengan indikator promosi berdasarkan kinerja berada pada rata-rata 3,71 dengan kriteria jawaban puas, cara meningkatkannya dengan memberikan kesempatan promosi berdasarkan kinerja pegawai adalah cara yang efektif untuk mempertahankan pegawai yang memiliki kualitas kerja yang baik dengan memberikan kesempatan promosi bagi pegawai potensial tersebut. Untuk indikator promosi berdasarkan lama kerja berada pada rata-rata 3,75 dengan kriteria jawaban puas, cara meningkatkannya dengan memperhatikan dalam memberikan penghargaan berupa promosi kepada pegawai yang sudah lama mengabdi di kantor.

Pada dimensi mutu pengawasan supervisi dengan indikator pengawasan bimbingan yang diberikan dengan rata-rata 3,64 dengan kriteria jawaban puas, cara meningkatkannya sebaiknya pemimpin memberikan bimbingan berupa motivasi yang terarah tentang standar operasional prosedur dalam sebuah kantor, agar aktivitas di dalam kantor berjalan dengan baik. Untuk indikator tingkat perhatian yang diberikan atasan berada pada rata-rata 3,29 dengan kriteria jawaban cukup puas, cara meningkatkannya sebaiknya pemimpin melakukan observasi secara langsung dan memperhatikan setiap pekerjaan pegawai. Pada dimensi rekan kerja dengan dimensi kondisi hubungan dengan rekan kerja berada pada rata-rata 3,71 kriteria jawaban puas. Cara meningkatkannya dengan menjalin komunikasi yang baik, dan saling mendukung antara pegawai yang satu dengan pegawai lainnya.

Dalam hal ini dapat ditarik kesimpulan bahwa kepuasan kerja pada Kantor Pelayanan Perbendaharaan Negara (KPPN) Pematangsiantar sudah di kategorikan puas. Walaupun sudah puas, 
pemimpin sebaiknya memberikan bimbingan berupa motivasi yang terarah dan melakukan observasi secara langsung serta memperhatikan setiap pekerjaan pegawai, agar aktivitas di dalam kantor berjalan dengan baik. Hal yang demikian akan lebih meningkatkan kepuasan kerja pegawai.

\section{c. Disiplin Kerja Pegawai Pada Kantor Pelayanan Perbendaharaan Negara (KPPN) Pematangsiantar}

Berdasarkan hasil rekapitulasi penelitian, maka diperoleh hasil penelitian yang menyatakan bahwa disiplin kerja pegawai pada Kantor Pelayanan Perberdaharaan Negara (KPPN) Pematangsiantar sudah dalam kategori baik. Hal ini dapat dilihat dari jawaban responden dengan nilai keseluruhan ratarata sebesar 3,89 dengan kriteria jawaban baik.

Pada dimensi menjalankan kewajiban dengan indikator menaati peraturan perundang- undangan berada pada rata-rata 3,83 dengan kriteria jawaban baik, cara meningkatkannya dengan menumbuhkan kesadaran dalam diri pegawai akan pentingnya menaati peraturan dan norma-norma yang terkandung pada perundang-undangan. Pada indikator melaksanakan tugas kedinasan berada pada rata-rata 3,82 dengan kriteria jawaban baik, cara meningkatkannya dengan memberikan teguran dari pimpinan bagi pegawai yang tidak melakukan tugas kedinasan. Pada indikator menaati ketentuan jam kerja berada pada rata-rata 3,21 dengan kriteria cukup baik, cara meningkatkannya dengan melaksanakan sanksi atau hukuman yang lebih tegas yang menimbulkan efek jerah sehingga pegawai tidak mengulanginya. Pada indikator mencapai sasaran kerja pegawai berada pada rata-rata 3,75 dengan kriteria jawaban baik, cara meningkatkannya pemimpin sebaiknya memberikan motivasi agar kinerjanya meningkat. Pada indikator menaati peraturan kedinasan berada pada rata-rata 2,96 dengan kriteria cukup baik, cara meningkatkannya dengan memberikan sanksi yang tegas dan konsisiten bagi pegawai yang melanggar peraturan kedinasan.

Pada dimensi menjauhi larangan menyalahgunakan wewenang berada pada rata-rata 3,50 dengan kriteria jawaban baik, cara mengatasinya dengan mengadakan acara untuk menciptakan rasa kebersamaan antara pegawai senior dengan junior untuk menjalin komunikasi yang baik antar pegawai.

Pada indikator bekerja pada perusahaan asing berada pada rata-rata 3,29 dengan kriteria jawaban cukup baik, cara mengatasinya dengan melakukan sosialisasi pada pegawai untuk menumbuhkan rasa nasionalisme. Pada indikator memiliki barangbarang milik negara secara tidak sah berada pada rata-rata 3,71 dengan kritria jawaban baik, cara mengatasinya dengan memberikan teguran lisan maupun tulisan pada pegawai yang melakukannya. Pada indikator memberikan hadiah kepada sesorang untuk diangkat dalam jabatan berada pada rata-rata 3,79 dengan kriteria jawaban baik, cara mengatasinya dengan melakukan teguran secara langsung karena hal ini merupakan tindakan penyuapan. Pada indikator mendukung calon peserta pemilu menggunakan fasilitas negara berada pada rata-rata 3,86 dengan kriteria jawaban baik, cara mengatasinya dengan menumbuhkan kesadaran pegawai bahwa fasilitas negara hanya digunakan untuk keperluan negara.

Dalam hal ini dapat diambil kesimpulan bahwa disiplin kerja pegawai pada Kantor Pelayanan Perbendaharaan Negara (KPPN) Pematangsiantar sudah dikategorikan baik. Walaupun sudah dikategorikan baik, kantor masih perlu menerapkan sanksi yang konsisten dan tanpa pandang bulu untuk memberikan efek jera bagi pegawai yang melanggarnya sesuai dengan peraturan yang dibuat pemerintah bagi pegawai negeri sipil (PNS).

\section{KESIMPULAN DAN SARAN}

\section{Kesimpulan}

a. Hasil analisis regresi linear berganda diperoleh nilai $\hat{Y}=35,010+0,490 X_{1}+0,763 X_{2}$, artinya terdapat pengaruh yang positif antara variabel etos kerja $\left(\mathrm{X}_{1}\right)$ dan variabel kepuasan kerja $\left(\mathrm{X}_{2}\right)$ terhadap disiplin kerja pegawai (Y) pada Kantor Pelayanan Perbendaharaan Negara (KPPN) Pematangsiantar.

b. Hasil analisis korelasi diperoleh nilai $r=0,781$ yang artinya terdapat hubungan yang kuat dan positif antara etos kerja $\left(\mathrm{X}_{1}\right)$ dan kepuasan kerja $\left(\mathrm{X}_{2}\right)$ terhadap disiplin kerja pegawai $(\mathrm{Y})$ pada Kantor Pelayanan Perbendaharaan Negara (KPPN) Pematangsiantar. Selanjutnya diperoleh koefisien determinasi $\mathrm{R}$ square 0,610 artinya tinggi rendahnya etos kerja dan kepuasan kerja dapat dijelaskan sebesar $61 \%$ oleh disiplin kerja pegawai, selebihnya 39\% dijelaskan oleh faktorfaktor lain seperti motivasi, kompensasi, lingkungan kerja, kinerja, komunikasi dan faktorfaktor lain yang tidak dibahas dalam penelitian ini.

c. Hasil pengujian hipotesis secara simultan dengan uji $\mathrm{F}$, diperoleh nilai $\mathrm{F}_{\text {hitung }}$ sebesar $19,537>\mathrm{F}_{\text {tabel }}$ $(0,05 ; 2$ VS 25$)$ sebesar 3,39 atau dengan taraf signifikan $0,000<\alpha 0,05$, maka $\mathrm{H}_{0}$ ditolak, artinya etos kerja dan kepuasan kerja berpengaruh positif dan signifikan terhadap disiplin kerja pegawai pada Kantor Pelayanan Perbendaharaan Negara (KPPN) Pematangsiantar.

d. Hasil pengujian hipotesis secara parsial dengan uji $t$, diperoleh nilai $t_{\text {hitung }}$ pada variabel Etos Kerja $\left(X_{1}\right)$ sebesar 3,660 $>\mathrm{t}_{\text {tabel }}$ dengan $\mathrm{df}=\mathrm{n}-\mathrm{k}-1$ $(28-2-1=25)$ sebesar 2,05954, atau dengan taraf signifikan $0,001<\alpha 0,05$, maka $\mathrm{H}_{0}$ ditolak, artinya etos kerja berpengaruh positif dan signifikan terhadap disiplin kerja pegawai pada Kantor Pelayanan Perbendaharaan Negara (KPPN) Pematangsiantar secara parsial. Sedangkan $t_{\text {hitung }}$ pada variabel kepuasan kerja $\left(\mathrm{X}_{2}\right)$ sebesar 3,652 $>\mathrm{t}_{\text {tabel }}$ dengan $\mathrm{df}=\mathrm{n}-\mathrm{k}-1$ (28$2-1=25$ ) sebesar 2,05954, atau dengan taraf signifikan $0,001<\alpha 0,05$, maka $\mathrm{H}_{0}$ ditolak, artinya kepuasan kerja berpengaruh positif dan signifikan terhadap disiplin kerja pegawai pada 
Kantor Pelayanan Perbendaharaan Negara (KPPN) Pematangsiantar.

\section{Saran}

a. Untuk mendorong etos kerja pada Kantor Pelayanan Perbendaharaan Negara (KPPN) Pematangsiantar, sebaiknya pegawai lebih suka bekerja keras, tidak membuang-buang waktu selama jam kerja, mau bekerjasama, dan hormat kepada rekan kerja.

b. Untuk meningkatkan kepuasan kerja pegawai pada Kantor Pelayanan Perbendaharaan Negara (KPPN) Pematangsiantar, pemimpin sebaiknya memberikan bimbingan berupa motivasi yang terarah, melakukan observasi secara langsung, memperhatikan setiap pekerjaan pegawai dan mengetahui yang menjadi keinginan pegawai.

c. Untuk mengoptimalkan disiplin kerja pegawai pada Kantor Pelayanan Perbendaharaan Negara (KPPN) Pematangsiantar, sebaiknya kantor menerapkan sanksi yang konsisten dan tanpa pandang bulu untuk memberikan efek jera bagi pegawai yang melanggarnya sesuai dengan peraturan yang dibuat pemerintah bagi pegawai negeri sipil (PNS).

d. Sehubungan dengan keterbatasan-keterbatasan yang ada pada penulis, penelitian ini masih terdapat kelemahan-kelemahan dan belum dapat mengungkap seluruh variabel yang dapat mempengaruhi disiplin kerja pegawai Kantor Pelayanan Perbendaharaan Negara (KKPN) Pematangsiantar. Sebagai bahan masukan untuk penelitian selanjutnya, perlu memperbanyak variabel penelitian yang tidak dibahas dalam penelitian ini.

\section{E. DAFTAR PUSTAKA}

Anoraga, Panji. 2009. Manajemen Bisnis. Jakarta: PT Rineka Cipta

As'ad, M. 2003. Sumber Daya Manusia Psikologi Industri. Edisi Keempat. Yogyakarta: Liberty

Asifudin, Ahmad Janan. 2004. Etos Kerja Islami. Surakarta: Universitas Muhammadiyah Press.

Gomes, Faustino Carsodo. 2003. Manajemen Sumber Daya Manusia. Yogyakarta : Penerbit Andi.

Luthans. 2005. Perilaku Organisasi. Yogjakarta: Penerbit Andi.

Mathis, Robert L. dan John H. Jackson. 2006. Human Resource Management (Manajemen Sumber Daya Manusia). Edisi 10. Jakarta: Salemba Empat.

2011. Human Resource Management (Manajemen Sumber Daya Manusia). Edisi 10. Jakarta: Salemba Empat.

Mondy, Wayne. 2008. Manajemen Sumber Daya Manusia. Jakarta: Erlangga.

Peraturan Pemerintah Republik Indonesia Tahun 2010. Nomor 53 tahun 2010 tentang
Disiplin Pegawai Negri Sipil.

Priansa, Donni Juni. 2014. Perencanaan dan Pengembangan Sumber Daya Manusia. Bandung: Alfabeta

Sinamo, Jansen. 2005. Delapan Etos Kerja Professional. Jakarta: Institut Darma Mahardika.

Sutrisno, Edy. 2011. Manajemen Sumber Daya Manusia. Edisi Pertama. Cetakan Ketiga. Jakarta: Kencana.

Zainal, Veithzal, et. al. 2015. Manajemen Sumber Daya Manusia untuk Perusahaan dari Teori Praktik. Edisi Ketiga. Jakarta: PT Raja Grafindo Persada. 